\title{
U.S. Climate and Energy Policy: \\ What Went Wrong, and What it Means for Global Renewable Energy \\ Technology Development
}

\author{
Elias Hinckley \\ Kilpatrick Townsend \& Stockton LLP, Washington, DC, USA \\ Georgetown University, Washington, DC, USA \\ Tel: +202.824.1444, Fax: +202.585.0015, E-mail: eh@georgetown.edu
}

\begin{abstract}
This paper examines the breakdown in discussion and the legislative process in the U.S. Government that led to the surprising failure to enact meaningful energy or climate legislation during the first two years of the Obama Presidency, while his Democratic party held control over the Government, including factors like opposition, the legislative process, the Gulf oil spill, and lack of understanding. From this critical understanding the paper will examine where U.S. policy stands today, and what the likely path forward for U.S. energy and climate policy may be and how those policy decisions absent climate legislation will effect renewable energy technology development and deployment in the U.S. and global marketplace over the coming years.
\end{abstract}

Keywords: Policy, Renewable energy, Climate, U.S., Greenhouse gases

\section{Introduction}

While reports have the U.S. slipping behind China as the now second largest consumer of energy on the globe, [1] U.S. action on climate and energy remains one of the critical pieces of the global policy discussion about the future of renewable energy.

Proponents of climate change legislation in the U.S., were dealt a stunning defeat when the U.S. Senate failed to reach a consensus and pass a climate and energy law. In November of 2008 the Democrats won a 'supermajority' in Congress and took control of the White Houseseemingly the only question was how quickly the U.S. would take a global leadership role on climate change. More than 2 years into the Obama Presidency, no significant law on climate change or energy policy has been enacted, and the path forward for a changed energy and emission policy in the U.S. remains strikingly opaque.

\section{Methodology}

Following several inquiries about the process and explanations for the failure of the U.S. congress to pass comprehensive climate legislation during 2010 the author began to compile information on the process through major media coverage, direct interviews with members of the U.S. congress and their respective staffs. In combination with available information on U.S. and global energy markets, this collected information was analyzed to determine why legislation was not passed, and what the near-term future of U.S. energy and climate policy will likely be.

\section{What Went Wrong}

That the U.S. Government did not pass a comprehensive carbon cap and trade law during 2009 or 2010 was surprising to many observers both inside and outside of the U.S. The consensus government, with Democrats controlling the White House, House of Representatives and with a super majority in the Senate, appeared perfectly positioned to act on the campaign promises of Barack Obama that the U.S. would act in a meaningful way on climate change by signing greenhouse gas limits into law, would take a leading role in 
managing greenhouse gases globally, and accelerate the development of a clean energy economy. For proponents of renewable energy this inaction by the U.S. government, while Democratic supporters were so well positioned to take decisive steps on both climate and energy, was seen as significant failure.

The first hint that the passage of sweeping legislation related to climate change might face substantial headwinds despite the Democratic control of the government came in the weeks leading up to the Conference of Parties in Copenhagen in December of 2009. Despite Obama's publically expressed desire to go to Copenhagen with a new U.S. law as a base for negotiations there was little compromise in the month leading up to the COP on what that platform would be and effectively no legislative action. [2] With results from the Copenhagen meeting providing less clarity on the future plan for global climate change action than supporters had hoped (and with many pointing to the U.S.'s unwillingness to commit as a key reason why there was not more progress during the Copenhagen talks), the President returned to the U.S. again pledging action on new laws in the U.S. [3]

Throughout the winter and spring following Copenhagen, the debate over U.S. climate and energy policy circled around two proposals which were both based on cap and trade programs similar to the EU's cap and trade scheme designed to reduce greenhouse gas emissions. The American Clean Energy and Security Act of 2009 (also known as the Waxman-Markey Bill) was passed by the House of Representatives in June of 2009.[4] Several members of the U.S. Senate worked to pass a companion bill which could be reconciled with Waxman-Markey and then sent to the President to be signed into law. Of the many ideas and positions that were raised, the leading option that eventually took center stage in the Senate was a proposed collaboration by Sen. John Kerry, a Democrat, Sen. Joe Lieberman, an Independent and Sen. Lindsay Graham, a Republican. This bill, nicknamed KGL, was eventually drafted and formally introduced in the Senate, but not before Sen. Graham had splintered from the group citing concerns over Democratic action over immigration policy, growing concerns about the potential negative economic impact of cap and trade and tremendous pressure from some of his Republican colleagues.

The resulting bill, the American Power Act [5] was introduced late in the Spring of 2010. Timing, increased partisanship over energy and climate, lingering economic concerns, and a strong lobbying presence by fossil fuel companies, all combined to limit substantive discourse on this bill. By the time the bill was actually introduced on May $12^{\text {th }}$ the Senate was nearly through its Spring session leaving only a light Summer schedule, which ended at the start of August under the $111^{\text {th }}$ Congress [6] to debate and vote on legislation that was both divisive and complex on an unprecedented scale. Republicans pulled together in an increasingly tight anti-climate block during this period, pointing to potential economic damage to a still weak U.S. economy. Similarly, fractures in the Democratic majority over those economic concerns and tremendous uncertainty about broader energy policy questions as the Deepwater Horizon spill in the Gulf of Mexico continued unabated though the summer eroded support and slowed the debate process. During this period the fossil fuel industry waged a coordinated lobbying effort to erode the support of both Democrats and Republicans for the bill by highlighting the potential increases in energy costs and job losses. The result was that Democratic leadership in the Senate never managed to even get the bill brought up for a full vote by the Senate.

During this period a number of alternative proposals designed to directly support the renewable energy industry had been developed and introduced in both Houses of Congress. Bills ranging from national renewable energy standards to expanded renewable energy research and development funding to energy efficiency and building use targets all gained 
substantial support. Leadership kept the Climate Bill as effectively the first order of business, with the only other focus of the session being related to rules governing offshore drillingand there was even a movement to combine these two efforts into a sweeping climate and offshore drilling package. The result was that these two high-profile, but extremely divisive issues stayed in front of every other clean energy proposal and the Senate's summer session closed without even targeted energy legislation moving forward.

There is little doubt that the results of the recent congressional elections in the U.S. will mean less support for incentives or new regulation that benefit the manufacture or deployment of renewable energy facilities. Republicans now control the House of Representatives. The party has, broadly, been less supportive of renewable energy integration or of restrictions on $\mathrm{CO}_{2}$ emissions. This lack of support has found very specific backing by several members who are attacking the science underlying the connections between fossil fuel use and climate change, as well as the widely held belief that the integration of energy resources, which are viewed as more expensive than traditional energy mix, will cause irreparable damage to an already struggling economy. This includes very open attacks by the members who vied for control of the House Energy and Commerce Committee, which was eventually won by Rep. Fred Upton. [7]

\section{Where U.S. Policy Stands}

The current make-up of the U.S. government makes it difficult for either party to pass a new law. Democrats control the Senate and the White House while Republicans hold a strong majority in the House of Representatives. In order for a new law to be enacted, it must pass both the House and the Senate (and because of procedural rules, the minority party can prevent a proposed law or bill from passing by using a minority block of 41 votes to prevent a bill from being debated or voted upon. [8] Only after passage in both chambers of Congress is the bill sent to the President, who would then sign the bill into law or exercise his power of veto to reject the bill.

Given the divide that has been growing between Democrats and Republicans over energy and climate, the current split in the control of Congress means that finding areas of compromise on energy or climate issues will be difficult, if not impossible over the next two years.

A national cap and trade bill is very clearly not a viable near-term option. The next presumed Speaker of the House, Rep. John Boehner, commented before the election that "This election is going to be a referendum on [Democrats'] job-killing policies, one of which is cap and trade," Boehner said. "There will be no tax increases; there'll be no cap and trade bill," he added. [9] The failure of Democratic leadership to consolidate support this past summer to pass comprehensive climate legislation, combined with an increase of climate-science denial rhetoric by the Tea Party and the far-right of the Republican party means that there is simply no path to legislate a national price on greenhouse gases over the next two years (unless there is some very significant exigent event that dramatically focuses public perception on climate change).

It seems very clear that natural gas, and possibly nuclear power, will play a meaningful role as lower-carbon options in the policy focus for both the power and transportation sectors over the next few years. Natural gas, as an expandable source of electric generation (and as a potential power source to meet increased demand from the electrification of the transportation sector, which has broad support of both Democrats and Republicans) and as a direct use fuel in the transportation fleet, appears to be the most likely near term area of policy compromise. 
There is substantial and inexpensive domestic supply of natural gas supported by the rapid growth in recoverable unconventional or shale gas made available by advances in hydrological fracturing technology. As this is domestically sourced fuel, this new expansion of natural gas supply is seen to address energy security and trade imbalance concerns. Additionally, on a relative basis natural gas has a much lower carbon output than the current energy supply mix in the U.S., so a shift to natural gas is seen as a step towards cutting greenhouse gas emissions. When speaking at a press conference following the election, President Obama indicated his support of natural gas development, "We've got, I think, broad agreement that we've got terrific natural gas resources in this country," Obama said. "Are we doing everything we can to develop those?” [10]

A rapid expansion (relative to the typical pace of energy infrastructure development) of natural gas use and demand is likely if part of an energy bill includes incentives to switch from coal to natural gas fired electric generation. The scale and pace of the demand expansion is unclear, and it will be limited by the available economically-competitive excess natural gas supply (and the real cost of new nuclear development as that becomes better understood). It is not clear at this early stage whether the election results will dramatically change the landscape with respect to environmental regulations related to non-conventional gas extraction (specifically for shale gas and the issues associated with hydraulic fracturing), as there is effectively no Federal oversight of these activities currently in place, though there are rules enforced at by state governments. A meaningful set of environmental controls could eventually act to slow available low-cost gas supplies and limit the role of natural gas as the driver of U.S. energy policy. In any event, the use of natural gas will likely be the lead approach in all energy and climate policy platforms developed in the U.S. over at least the next two years.

Another dynamic at play in the national policy debate around greenhouse gas limitations is that there are a series of rules being drafted by the EPA under its authority to manage greenhouse gas emissions under the Clean Air Act.[11] The Clean Air Act, however, does not include any specific language with respect to greenhouse gases, and whether and how the Act should be applied to carbon emissions is a point of considerable acrimony. Republicans in the House have already pledged to attack the EPA directly as well as through funding cuts to slow this rulemaking process.

This attack the EPA regulation of greenhouse gases will be a priority for Republicans, and the initial reaction from the Obama Administration is that it will work to find a compromise on the scope and pace of EPA regulation of greenhouse gases in exchange for other policy platforms that will act as alternative carbon mitigation tools, such as expanded use of renewables power and natural gas as a coal replacement. President Obama reinforced the idea this week, stating that "the EPA is under a court order that says greenhouse gases are a pollutant that fall under their jurisdiction. . . Cap and trade was just one way of skinning the cat; it was not the only way. . . And I'm going to be looking for other means to address this problem. . . I think EPA wants help from the legislature on this. I don't think that the desire is to somehow be protective of their powers here. I think what they want to do is make sure that the issue is being dealt with."'[12]

\section{Where Does the U.S. Go From Here}

As things currently stand it appears that any action on energy (or climate) by the U.S. Government will be cautious and targeted. Given the failures of several attempts at comprehensive policy changes, the safer and therefore more likely near-term approach will be 
small, targeted initiatives. These targeted policy platforms tend be directed at specific industries and have historically been incentive based. Some of these platforms can actually be contradictory, as constituencies push for support of their own areas of focus without regard for the broader energy or climate policy landscape. The result is that short term market distortions and the lack of long term certainty of price signals reduces investor appetite in all segments of industry development. Even when considered in concert with the broad concerns over the lack of a developed approach to national energy and climate challenges, these problems will almost certainly not be an adequate incentive to revisit a more sweeping approach to energy or climate policy for at least the next two years.

The most likely program platform will be direct incentive based programs have historically proven complex and challenging. Especially for non-U.S. based companies, requiring a U.S. tax base or deep understanding of the U.S. tax system. Some programs require compliance with rules such as U.S. sourced materials and labor. The most significant support mechanism for renewable energy has been tax credits for the development or operation of renewable energy facilities. Most of these credits are in place through the term of the new Congress, with two notable exceptions. The credit for wind power generation is set to expire at the end of 2011 and will require legislative action in order to be extended. Also, the popular 1603 Grant program, which provides a direct payment in lieu of the tax credits is currently set to expire at the end of 2010, though this may be extended by a year through last minute dealings in the final days of the current "lame duck" Congress. These two programs, along with other popular programs like funding for energy research and development are a very real risk, despite widespread conceptual support, as the focus of government programs is turned to balancing the budget and deficit reduction. Extending or re-funding these programs may require matching offsets to produce the savings or revenue increases necessary to make the net cost to the government zero, which is an extremely contentious process.

Another popular program, at least from the Government's perspective is the Federal Loan Guarantee Program, which is administered by the U.S. Department of Energy and supports, among other things, the deployment of renewable energy technologies and manufacturing capacity. As with many of the direct incentive programs these guarantees have been complex and challenging to secure, which has been a source of substantial criticism from the industry and investors. Further, the potential default of some early guarantees may also bring potential program costs into sharp focus as further program funding is contemplated, leaving the future of these programs in some doubt.

Enactment of a national clean energy standard is one broad platform possibility in the coming months (and a program may be enacted by the time of the World Renewable Energy Congress). Renewable Energy Standards have been a popular state government tool, but despite several attempts the program has never been enacted at the national level. These programs are generally structured so that the local distribution company is required to hold Renewable Energy Certificates (RECs) commensurate with a set percentage of power that is required to be produced from identified renewable resources. Production of renewable power creates a REC for every unit of power that is produced, which can be sold along with the power or separately. Due to its regulatory requirements to hold some number of RECs, the local distribution company sets overall demand (possibly in combination with some voluntary buyers) based its need to meet the target for renewable power purchases.

It appears likely that in the near term states and regional programs will take the lead on climate specific rule-making (and possibly more aggressive renewable power targets). As many states as many as 33 states have some form of renewable portfolio standard in 
operation. A handful of states have begun to experiment with feed-in-tariff programs similar to those used in Germany and Spain to drive rapid growth in solar and wind development. Several northeastern states are part of the Regional Green House Gas Initiative, which is a low-cost carbon cap and trade program for electric production facilities within member states, and in the Western US, the Western Climate Initiative as well as aggressive targets for California are both driving the development of regional markets. These state based programs have generally been embraced by the public and local politicians, at least sufficiently to see programs enacted and expanded. During the mid-term elections that saw historic Republican victories, California voters rejected a challenge to that state's cap and trade law, and New Mexico simultaneously enacted its own cap and trade program.

\section{Impact of Inaction by the U.S. on Global Energy and Climate Developments}

The slow pace with which the U.S. is embracing clean energy and climate policies will mean that deployment opportunities in the U.S. market will remain limited. The U.S. accounts for as much as $25 \%$ of global energy resource consumption, and the lack of U.S. commitment will create friction against the pace of a global energy transition. Given the scale of the U.S. energy economy, its pool of available energy investors, and the fact that the lack of clearly defined market for much of the new technology due to the lack of policy clarity will lead to less talent being engaged in the development of clean energy technology and business than would otherwise be engaged in the U.S., this resistance will be a drag on the pace of global growth for renewable power.

Despite the absence of the U.S. as a fully engaged stakeholder in this global energy and climate transformation, the absolute scale of the global opportunity will keep some U.S. companies and investors engaged in the new energy economy and continue to drive some U.S. investment into these industries. This limited role by the U.S. market will lead to better opportunities in both those developed nations where policy is better defined and in developing nations where sharp demand growth in fuelling investment. Development of renewable energy in Europe has matured more quickly than in in the U.S., as it has been supported by the EU ETS and targeted renewable energy programs like feed-in-tariffs combined with higher energy prices. In China aggressive government driven development programs have accelerated the maturity of the clean energy industry there, and by some accounts China has overtaken the U.S. in clean energy investments.[13]

\section{Conclusion}

Inaction by the U.S. Congress on climate and energy policy has created a great deal of uncertainty in the both the U.S. and global energy marketplace. Short-term relief for companies with exposure to greenhouse gas emission limitations will quickly give way to challenges planning for mid- and long-term investment choices. This uncertainty is intensified when combined with a likely increase in volatility in the global oil market. The one point of confidence that all stakeholders can work from is that the fall-out from this legislative push for climate legislation all but guarantees that for the next few years (notwithstanding a significant disruptive event), the path forward in the U.S. will be driven locally, or in very measured steps nationally. As arguably the most important energy market in the world, the lack of clear long-term market signals in the U.S. will continue to impair the real value of many new energy and emission mitigation technologies. 


\section{References}

[1] China Tops U.S. in Energy Use, Spencer Swartz and Shai Oster, Wall Street Journal, July 18, 2010.

[2] John M. Broder, As Time Runs Short for Global Climate Treaty, Nations May Settle for Interim Steps, N.Y.Times, October 20, 2009.

[3] Barack Obama, Remarks by the President on the Economy at Carnegie Mellon University, http://www.whitehouse.gov/the-press-office/remarks-president-economycarnegie-mellon-university (Last visited Dec. 15, 2010).

[4] H.R. 2454, American Clean Energy and Security Act of 2009.

[5] American Power Act Unreleased Draft, http://climateprogress.org/wpcontent/uploads/2010/05/PowerActDraft 051110.pdf (last visited Dec. 15, 2010).

[6] Congress was in session for September and October prior to the election, but doe to the extended campaign period leading into the election there was no reasonable expectation of action during this period; similarly the lame duck period following the election carries additional procedural hurdles that made action impossible.

[7] Office of Congressman Joe Barton, Climate Change and Policy Implications, http://joebarton.house.gov/Issues.aspx?Section=52 (last visited Dec. 15, 2010).

[8] This process, the filibuster, is a procedural peculiarity of the Senate and provides a great deal of power to the minority party to block legislation.

[9] Elana Schor, Election a Rreferendum on Democrats' Support for Cap and Trade Boehner, GreenWire, October 2010, http://www.eenews.net/Greenwire/2010/10/05/archive/5?terms=boehner.

[10] Press Conference by the President (November 3, 2010), available at: http://www.whitehouse.gov/the-press-office/2010/11/03/press-conference-president.

[11] 40 CFR Part 51, 52, 70, 71, Prevention of Significant Deterioration and Title V Greenhouse Gas Tailoring Rule, June 3, 2010 and 40 CFR Part 52, Action to Ensure Authority to Issue Permits Under the Prevention of Significant Deterioration Program to Sources of Greenhouse Gas Emissions: Federal Implementation Plan, August 23, 2010; et al.

[12]Id.

[13] The PEW Charitable Trusts, Who's Winning the Clean Energy Race? Growth, Competition and Opportunity in the World's Largest Economies, http://www.pewglobalwarming.org/cleanenergyeconomy/pdf/PewG-20Report.pdf (last visited Dec. 15, 2010). 